\title{
The development of the "Bawi Kuwu" learning model in the text writing material of the observation report
}

\author{
Indra Perdana*), \\ Universitas Negeri Palangka Raya \\ *) Correspondences author: Jl. Yos Sudarso, Palangka, Jekan Raya, Kota Palangka Raya, Kalimantan Tengah 74874, Indonesia \\ e-mail: Indra.perdana@fkip.upr.ac.id
}

\begin{abstract}
The application of the learning model is an operational step to achieving maximum learning goals. Based on the results of the author's observation on Indonesian Language subjects, especially in the field of writing skills, the Report on Observation Results (LHO) is often found to be a problem, students find it difficult to make sentences and paragraphs of LHO text. This is because the teacher often implements an inappropriate learning model, so students have not been able to fully understand the concept of the LHO text. The selection of creative and innovative learning methods and models can influence the ability of students to construct their knowledge well. The application of creative and innovative learning models can also be developed from a local wisdom in each region, for example the local wisdom of Bawi Kuwu folklore in Central Kalimantan. Folklore Bawi Kuwu can be modified into a learning model by paying attention to the cultural value of the story. The Bawi Kuwu (BK) learning model is a group learning model based on the cultural value of folklore in Central Kalimantan and the collaboration between the concept of cooperative jigsaw learning models and peer teaching. The application of the Bawi Kuwu learning pattern in writing the Observation Results Text is very suitable to be applied because in its application the students in the group try to construct their knowledge and convey it to a student in his group with the guidance of the teacher.
\end{abstract}

Key Words: Bawi Kuwu Learning Model, Text Report on Observation Results.

Article History: Received: 12/10/2018; Revised: 11/11/2018; Accepted: 02/12/2018; Published: 25/12/2018

How to Cite (MLA 7 ${ }^{\text {th }}$ ): Perdana, Indra. "The development of the "bawi kuwu" learning model in the text writing material of the observation report." Hortatori Jurnal Pendidikan Bahasa dan Sastra Indonesia 2.2 (2018): 69-73. Print/Online. Copyrights Holder: Perdana, Indra. First Publication: Hortatori Jurnal Pendidikan Bahasa dan Sastra Indonesia (2018).

\section{Pendahuluan}

Masalah utama belajar dalam pendidikan formal (sekolah) adalah masih rendahnya daya serap peserta didik. Hal ini nampak dari rata-rata hasil belajar Bahasa Indonesia peserta didik yang senantiasa masih sangat memprihatinkan. Prestasi ini tentunya merupakan hasil kondisi pembelajaran yang masih banyak bersifat konvensional dan tidak menyentuh ranah dimensi peserta didik itu sendiri. Pada umumnya, proses pembelajaran lebih banyak di dominasi guru dan tidak memberikan akses bagi anak didik untuk berkembang secara mandiri melalui penemuan dalam proses berpikirnya.

Secara empiris, berdasarkan hasil analisis penelitian terhadap rendahnya hasil belajar peserta didik disebabkan karena dominannya proses pembelajaran konvensional. Pada pembelajaran ini suasana kelas cenderung teacher-centered sehingga peserta didik menjadi pasif. Meskipun demikian guru lebih suka menerapkan model tersebut, sebab tidak memerlukan alat dan bahan praktik, cukup menjelaskan konsepkonsep yang ada pada buku ajar atau referensi lain. Peserta didik tidak diajarkan strategi belajar yang dapat memahami bagaimana belajar, berpikir dan memotivasi diri sendiri, padahal aspek-aspek tersebut merupakan kunci keberhasilan dalam suatu pembelajaran khususnya pembelajaran Bahasa Indonesia. 
Pembelajaran Bahasa Indonesia diarahkan untuk meningkatkan kemampuan peserta didik dalam berkomunikasi menggunakan bahasa Indonesia dengan baik dan benar. Ruang lingkup mata pelajaran Bahasa Indonesia mencakup 4 keterampilan berbahasa, yaitu: menyimak, berbicara, membaca, dan menulis. Berdasarkan fakta, seringkali guru mengalami kesulitan dalam mengajar Bahasa Indonesia kepada peserta didik. Ada banyak sekali faktor yang menyebabkan kegagalan dalam pembelajaran, salah satunya adalah pemilihan model pembelajaran. Seringkali guru kurang kreatif dalam pembelajaran Bahasa Indonesia karena guru hanya menggunakan metode ceramah saja sehingga hasil belajar Bahasa Indonesia peserta didik rendah.

Model pembelajaran yang digunakan juga dapat memengaruhi hasil belajar peserta didik. Pada umumnya guru selalu menggunakan model pembelajaran gaya klasikal (kelas) dengan 1 guru dan banyak siswa. Padahal sebenarnya model dalam pembelajaran itu dapat diinovasikan dari suatu kebudayaan atau kearifan lokal yang ada di suatu daerah. Contohnya seperti di Kalimantan Tengah, mengenai cerita Bawi Kuwu (gadis pingitan) yang semenjak kecil dilarang oleh orang tuanya untuk keluar rumah dan hanya belajar segala sesuatu dari orang tua, keluarga, atau orang yang dekat dengannya di rumah. Menurut cerita, Bawi Kuwu tumbuh menjadi wanita yang cantik dan pintar dalam mengerjakan berbagai keterampilan tangan seperti menganyam, dan membuat prakarya.

Pola pembelajaran dari cerita Bawi Kuwu ini dapat diinovasikan sebagai sebuah pengembangan model pembelajaran dalam pendidikan. Misalnya, dalam satu kelas peserta didik dibentuk ke dalam beberapa kelompok belajar dengan suatu masalah atau topik tertentu. Lalu, bagi tugas peserta didik dalam kelompok sebagai yang mengajari (sebagai orang tua Bawi Kuwu) dan pilih satu orang yang diajari (sebagai Bawi Kuwu). Tingkat keberhasilan dalam model pembelajaran ini ditentukan oleh cara peserta didik yang mengajari dan pemahaman peserta didik yang diajari. Oleh karena itu, peserta didik yang mengajari memilih materi sesuai dengan kemampuannya. Model pembelajaran Bawi Kuwu, melatih peserta didik untuk bertanggungjawab, menghargai, memahami, bekerjasama, dan aktif berperan dalam pembelajaran. Jadi, pengembangan model pembelajaran Bawi Kuwu ini merupakan kebalikan dari model klasikal atau konvensional, di mana dalam suatu kelas terdapat banyak peran guru dan 1 orang yang berperan sebagai peserta didik. Implementasi model pembelajaran Bawi Kuwu ini dapat diuji coba pada pembelajaran Bahasa Indonesia khususnya pada pembelajaran menulis Teks Laporan Hasil Observasi.

Penerapan pola pembelajaran Bawi Kuwu pada kegiatan menulis Teks Hasil Observasi sangat cocok diterapkan karena pada penerapannya peserta didik dalam kelompok berusaha untuk mengonstruksi pengetahuannya dan menyampaikannya kepada seorang peserta didik di kelompoknya. Setelah itu setiap kelompok peserta didik akan bersama-sama mengobservasi suatu objek dengan pembagian tugas masingmasing dalam kelompok. Pada kegiatan ini, peserta didik dapat saling mengajarkan dan berbagi pengetahuan mengenai objek yang diobservasi sehingga diharapkan dapat membentuk sebuah teks yang terstruktur dengan baik.

\section{Hasil dan Diskusi}

Model pembelajaran Bawi Kuwu (BK) merupakan suatu model pembelajaran yang dikembangkan dari cerita rakyat di Kalimantan Tengah. Berdasarkan cerita, Bawi Kuwu merupakan seorang anak gadis yang dipingit (dilarang keluar rumah) oleh orang tuanya semenjak kecil. Bawi Kuwu tumbuh dan belajar hanya dari lingkungan keluarga dan orang terdekat di dalam rumah.

Model pembelajaran BK juga merupakan bentuk kreativitas dengan mengolaborasikan konsep model pembelajaran jigsaw kooperatif dan peer teaching. Pada lingkup model pembelajaran, makna kolaborasi dimaksudkan untuk menggabungkan dua atau lebih model pembelajaran yang diterapkan dalam waktu yang bersamaan dengan tujuan tertentu. Kolaborasi dua model pembelajaran tersebut akan melebur menjadi satu kesatuan dengan aturan yang baru berbeda dari asalnya. Pengolaborasian antara model pembelajaran ini dimaksudkan untuk membentuk suatu model pembelajaran inovatif yang sesuai dengan karakter dan kondisi siswa, sehingga tingkat keberhasilan dalam pembelajaran dapat lebih dimaksimalkan. 
Oleh sebab itu, model pembelajaran BK dapat diterapkan sebagai sebuah model pembelajaran inovatif di sekolah.

Menurut Arends (1997) model pembelajaran kooperatif jigsaw merupakan model pembelajaran kooperatif, dengan siswa belajar dalam kelompok kecil yang terdiri dari 4-6 orang secara heterogen dan bekerjasama saling ketergantungan yang positif dan bertanggung jawab atas ketuntasan bagian materi pelajaran yang harus dipelajari dan menyampaikan materi tersebut kepada kelompok yang lain. Sedangkan model pembelajaran peer teaching merupakan metode belajar yang melibatkan siswa secara aktif, satu siswa akan mengajari siswa lain yang mengalami kesulitan dalam memahami materi yang diberikan (Dianawati, 2015: 27).

\section{Penerapan model pembelajaran bawi kuwu}

Teknis pelaksanaan model pembelajaran BK adalah membentuk peserta didik menjadi beberapa kelompok yang bertanggung jawab untuk mengajari seorang teman dalam kelompok belajar dan memandang kelompok sebagai sebuah keluarga. Pendekatan yang digunakan dalam model pembelajaran BK adalah pendekatan kolaborasi konstruktivisme dan behaviorisme. Dalam model BK, peserta didik diarahkan untuk mencari dan membentuk pemahaman mereka sendiri kemudian mengomunikasikan pemahaman tersebut kepada teman dalam kelompok belajar. Berikut merupakan langkah-langkah penerapan model pembelajaran BK:

1. Peserta didik dibentuk menjadi beberapa kelompok belajar (kelompok Heterogen).

2. Setiap kelompok diberikan tugas untuk mengobservasi objek yang berbeda.

3. Dalam keheterogenan kelompok, setiap kelompok memilih 1 orang sebagai objek yang akan diberikan stimulus atau diajarkan.

4. Setelah dipilih, 1 orang tersebut akan dipindahkan ke kelompok yang lain sebagai Bawi Kuwu. Misalnya:

5. Setiap kelompok difilosofikan sebagai sebuah keluarga Bawi Kuwu.

6. Setiap keluarga bertanggung jawab dan bertugas mengajarkan $\mathrm{Bk}$ untuk memahami topik yang dibahas pada kelompok tersebut

7. Pada akhirnya Bk akan di test keterampilan menulis teks LHO. Pada tahap ini kelompok/keluarga membantu dan membimbing Bk serta memberikan tanggapan, penilaian untuk Bk (self assessment).

Kekuatan dari model BK ini sebagai model pembelajaran adalah mengajarkan rasa tanggung jawab, kerja sama, dan kepedulian kepada peserta didik dengan cara menciptakan suasana kelompok belajar menjadi sebuah keluarga yang memiliki tugas dan fungsi masing-masing.

\section{Filosofi pembelajaran bawi kuwu}

$\begin{array}{llll}\text { B } & \text { : Bermakna } & \mathrm{K} & \text { : Kreatif } \\ \mathrm{A} & \text { : Aktif } & \mathrm{U} & \text { : Unik } \\ \mathrm{W} & \text { : Wawasan } & \mathrm{W} & \text { : Wicara (tutur kata/komunikasi) } \\ \mathrm{I} & \text { : Imaginatif } & \mathrm{U} & \text { : Upaya }\end{array}$

Model BK merupakan model pembelajaran yang bermakna karena dalam prosesnya peserta didik mengkonstruksi apa yang dipelajari kemudian mengasosiasikan pengalaman, fenomena, fakta-fakta baru ke dalam sistem pengertian yang telah dimilikinya.

Model BK merupakan model pembelajaran yang aktif karena peserta didik dipacu untuk mengeksplorasi pengetahuan dan pengalaman sendiri, termasuk sikap, nilai, kepercayaan, dan motivasi diri sendiri. Model BK merupakan model pembelajaran yang menambah wawasan peserta didik mengenai cerita rakyat atau legenda Bawi Kuwu di provinsi Kalimantan Tengah (Kontekstual). 
Model BK juga merupakan model pembelajaran imaginatif karena dalam pembelajaran peserta didik menggambarkan kelompok belajar sebagai keluarga yang memiliki tugas dan peran masing-masing.

Model BK adalah model pembelajaran yang kreatif karena dikembangkan dari cerita rakyat di Kalimantan Tengah, dan juga hasil dari kolaborasi model pembelajaran sehingga menjadi suatu penemuan model pembelajaran yang baru di sekolah.

Model BK juga merupakan model pembelajaran yang unik karena merupakan hasil kolaborasi model pembelajaran dengan konsep yang berbeda dari model pembelajaran yang membentuknya.

Model BK merupakan model pembelajaran yang melatih kemampuan berkomunikasi peserta didik (wicara) untuk menyampaikan pesan atau pemahamannya agar dipahami oleh peserta didik dalam kelompok belajar.

Model BK juga adalah suatu upaya yang mengembangkan kemampuan atau potensi peserta didik untuk lebih aktif dalam pembelajaran di kelas, serta upaya untuk mengembangkan model pembelajaran dari suatu kearifan lokal yang ada di daerah.

\section{Simpulan}

Model pembelajaran merupakan suatu langkah yang sangat penting untuk mencapai tujuan pembelajaran. Pemilihan model pembelajaran yang kreatif dan inovatif dapat meningkatkan hasil belajar peserta didik. Model pembelajaran bawi kuwu adalah suatu pengembangan model pembelajaran berdasarkan nilai budaya yang ada dalam cerita rakyat Kalimantan Tengah dan merupakan hasil kolaborasi dari model pembelajaran yang ada sebelumnya. Konsep pembelajaran bawi kuwu dapat diterapkan pada pembelajaran menulis teks LHO, karena proses menulis sebuah teks LHO merupakan sebuah proses yang kompleks bagi peserta didik sehingga membutuhkan bimbingan, bantuan, dan kerja sama bukan saja dari guru, melainkan juga peserta didik itu sendiri untuk membentuk pengalaman dan pengetahuaannya.

\section{Ucapan Terima Kasih}

Terima kasih kepada semua pihak yang telah membantu penulis menyelesaikan kajian ini. Terima kasih penulis ucapkan kepada editorial Hortatori sehingga hasil penelitian saya dapat diterbitkan di jurnal Hortatori.

\section{Daftar Rujukan}

Almerico, G.M. 2014. Building Character through Literacy with Children's Literature. Research in Higher Education Journal, Vol. 26(1), pp. 1-13.

Borg, W.R., and Gall, M.D. (1983) Educational Research; An Introduction. Fourth Edition. New York : Longman.

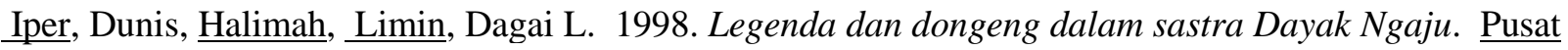
Pembinaan dan Pengembangan Bahasa

Emzir. (2010). Metodologi Penelitian Kualitatif: Analisis Data. Jakarta: PT Raja Grafindo Persada

Kosasih, E. 2013. Dasar-dasar Keterampilan Menulis. Bandung. YRama Widya. . 2014. Jenis-jenis Teks.Bandung:Yrama Widya.

Majid, Abdul. 2007. Perencanaan Pembelajaran. Bandung: Remaja Rosda Karya.

Mulyasa.H. 2013. Pengembangan dan Implementasi Kurikulum 2013. PT Remaja Rosdakarya.

Muktadir, A. \& Agustrianto. 2014. Pengembangan Model Mata Pelajaran Muatan Lokal Berbasis Kearifan Lokal untuk Meningkatkan Karakter di Sekolah Dasar Provinsi Bengkulu. Jurnal Pendidikan Karakter, Vol. 4(3), hlm.318-331.

Mungmachon, R (2013). Knowledge and Local Wisdom: Community Treasure. International Journal of Humanities and Social Science. Vol 2 No.13 July 2012 174-181

Prestwich, D.L. 2004. Character Education in America's Schools. The School Community Journal, Vol. 14(1), hlm. 139-150 
Taylor, J.L., Smith, K., Stolk A.P. dan Spiegelman G.B. (2010). "Using Invention to Change How Students Tackle Problems". CBE-Life Sciences Education Vol. 9, 504-512.

Tegeh, I Made, dkk. 2014. Model Penelitian dan Pengembangan. Yogyakarta: Graha Ilmu.

Trianto. 2009. Mendesain Model Pembelajaran Inovatif-Progresif. Jakarta: Prenada Media Group.

Yusuf, F.A \& Adeoye, E.A. 2012. Developing Critical Thinking and Communication skills in Students skills in student: Implications for practice in education" An International Multidiscplinary Journal. Ethiopia. Vol 6(1), Serial No 24 